\title{
The Season Effect on the Milk Fatty Acid Profile of Oulmes Breed Cattle in Moroccan Oulmes Zone
}

\author{
MahaEl-Hamdani ${ }^{1,2}$, AouatifBenali ${ }^{2}$, AbderraoufEl Antari ${ }^{3}$, Abdellah El \\ Housni $^{4}$, AhmedDouaik ${ }^{5}$, Khadija Ounine ${ }^{1}$ and Mohammed Bouksaim ${ }^{2 *}$ \\ ${ }^{1}$ Ibn Tofail University, Faculty of Sciences, P.O.Box 242, Kénitra, Morocco. \\ ${ }^{2}$ Laboratory of Food Technology, INRA, RCAR-Rabat, P.O. Box 6570, Rabat Institutes, 10101, Rabat, Morocco. \\ ${ }^{3}$ RUPlant Breeding and Quality, Food Technology Laboratory, INRA, RCAR-Marrakech, P.O. Box 533, \\ Marrakech 40000, Morocco. \\ ${ }^{4} R U$ Animal Production and Forage, INRA, RCAR-Rabat, Rabat Institutes, 10101, Rabat, Morocco. \\ ${ }^{5} R U$ Environment and Conservation of Natural Resources, INRA, RCAR-Rabat, Rabat Institutes, 10101, Rabat, \\ Morocco.
}

\begin{abstract}
In the present research work, we aimed to characterize the physicochemical quality and fatty acid profile of Oulmesbovine milk depending of season behavior. To perform this phenomenon, forty-eight samples were collected and examined in autumn 2013 and winter, spring, and summer 2014. The milk samples were obtained from Oulmes cows from the Middle Atlas region in Morocco. The milk components as milk fat, protein, and ash were observed not affected by seasonal change (3.6, 3.6 and 0.6\%, respectively), while the fatty acid profile has found changed considerably between seasons.It was noticed that Myristic, palmitic, stearic, and oleic acid were detected as the major fatty acids in the Oulmes cow milk. The saturated fatty acid(SFA)and monounsaturated fatty acid (MUFA) contentover the four seasons was higher, with a mean of 66.0 and 32.9\%, respectively.The essential $n-6$ and $n-3$ polyunsaturated fatty acids were not abundant in Oulmesmilk fat. Nevertheless, improving the diet of the animals could may increase n-3 fatty acid content and improve the source of $\alpha$-linolenic acid in milk fat.
\end{abstract}

Keywords: Oulmes breed, milk, physicochemical, fatty acids profile.

\section{Introduction}

It is generally known that cow's milk is an essential part of most daily diets andis a complex mixture of specific bioactive molecules such as proteins, lipids, saccharides, and biologically active substances including immunoglobulins, enzymes, oligosaccharides, hormones, and cytokines (Pouliot and Gauthier, 2006). Despite this, milk developed a bad reputation for contributing to cardiovascular disease because of its high saturated fat content. However, milk must not be marginalized in an average diet since, in addition to calcium and protein; it may alsohelp to prevent some cardiovascular and neoplastic diseases (Lecerf 2008).Some of these benefitsare due tothe fatty acid profiles of milk, some of which cannot be found in any other food.

Nevertheless, cow milk composition differs not only between species but also within species (Pougheon 2001), either through geneticsor farming practices.Cow's milk fat, in particular fatty acid profiles,is also affected by the diet of dairy cows (Palmquistet al., 1993; Dewhurst et al., 2006).This composition changes from summer to winter depending on the mode of feeding. Therefore, tracking livestock may be a solution to improvethe nutritional qualities of milk without dietary changes.

Nevertheless, cow feeding can be an important way to improvethe dietary qualities of milk fat.The aim of this workwas to investigate the diet of dairy cows and the fatty acid profiles of the produced milk during different seasons knowing that seasonal fluctuations are quantitatively significant and due mainly to changes in diet (Quist et al., 2008).

\subsection{Milk samples}

\section{Materials And Methods}

Fresh Oulmes milk was obtained from cows inhabiting theOulmes region during autumn 2013 andwinter, spring, and summer 2014. Oulmes is a rural place located $150 \mathrm{~km}$ northwest of Rabat andis in the high mountains of the Middle Atlas and middle hillssituated in the west in theAmazigh area.Ofthe main Moroccan local breeds, Oulmes-Zaerdatesto 1912 and wasrecognized by ministerial decree in 1982. It is an original Moroccan racereared for two purposes, milk and meat production, and it is well adapted to harsh environments (Boujenane, 2002). This region is also well known as a natural reserve of aromatic and medicinal plants(Chatibi, 2011). 
Forty-eight milk samples were collected in the early morning. The milk from each cow was collected directly in sterile bottles without preservative and kept at $4^{\circ} \mathrm{C}$. On arrival at the laboratory, all milk samples were stored at $-20^{\circ} \mathrm{C}$ untilchemical and fatty acid profiling.

\subsection{Chemical analysis}

The nitrogen content $(N)$ in the milk samples was estimated by Kjeldahl's method,and crudeprotein content was calculated as $N \times 6.25$. The ash content was obtained by incineration of thesample placed in a muffle furnace at $550^{\circ} \mathrm{C}$ for $6 \mathrm{~h}(\mathrm{AOAC}, 2000)$. The fat content was determined directly after collecting and processing using an auto-analyzer (LACTOSCAN ${ }^{\circledR}$ MilkAnalyzer) (Konyali, 2010).

\subsection{Analysis of fatty acids}

Milk fatty acid profiles were analyzed accordingto the procedure described by Akraimet al. (2005) with slight modifications.According to this method, fatty acid methylation is donein two stages: a basic methylation followed by an acid methylation that does not involve isomerization of cis-9, trans-11C18:2 (Duckettet al., 2002).

Milk samples were centrifuged at $10,000 \mathrm{x}$ g for $30 \mathrm{~min}$ at $5^{\circ} \mathrm{C}$ to harvest milk fat and then methylation was performed with $0.5 \mathrm{~N}$ methanolic $\mathrm{NaOH}$ followed by heating at $90^{\circ} \mathrm{C}$ for $10 \mathrm{~min}$. $14 \%$ boron trifluoride (BF3)was then added followed by a heating at $90^{\circ} \mathrm{C}$ for $10 \mathrm{~min}$.After addition of hexane and distilled water, the tubes were placed in a shaker for $10 \mathrm{~min}$ then centrifuged at $2880 \mathrm{x} \mathrm{g}$ for $15 \mathrm{~min}$.

\subsection{Analysis by gaschromatography}

Fatty acid methyl esters (FAMEs) were separated with a gas chromatograph (Varian CP 3380) equipped with a flame ionizationdetector using a Varian CP-Select CB capillary column $[50 \mathrm{~m} \times 0.25 \mathrm{~mm}$ (i.d.) with $0.39 \mathrm{~mm}$ (e.d.)]. Nitrogen was used as a carrier gas; the initial column temperature was $40^{\circ} \mathrm{C}$ held for $1 \mathrm{~min}$, after which the temperature was increased to $45^{\circ} \mathrm{Cat}$ rate $1^{\circ} \mathrm{C} / \mathrm{min}$ and from $45^{\circ} \mathrm{C}$ to $200^{\circ} \mathrm{C}$ at rate of $6^{\circ} \mathrm{C} / \mathrm{min}$. The temperature was kept at $200^{\circ} \mathrm{C}$ for the subsequent $40 \mathrm{~min}$. Injector and detector temperatures were set at $230^{\circ} \mathrm{C}$ and $250^{\circ} \mathrm{C}$, respectively. Fatty acid identification was carried out by comparing their retention times against fatty acid methyl standards. Resultsfor each fatty acid are expressed as a percentageof the sum of total FAs, and saturated FAs, monounsaturatedFAs, and PUFAs werecalculated.

\section{Statistical Analysis}

Results are expressed as means \pm standard deviation (SD). Significant differences between means were tested by ANOVA on arc transformed data followed by Tukey's studentized range test at $P<0.05$.

\subsection{Chemical composition}

\section{Results And Discussion}

The chemical characteristics of the 48 milk samples are shown in Figure 1.There was little variability between seasons. Oulmes breed milk protein ranged between 3 and $4 \%$ (mean $3.6 \%$ ), as found previously $(3.6 \%$ ) withaLactoscan milk analyzer (Elhamdaniet al., 2016). This value washigher than that found in Holstein cow milk from theLordegan region of Iran (3.3\%); (Mirzadehet al.,2010), Chinese Holstein cows in Northern China(3.1\%) (Yang et al., 2013), cows in Pakistan (3.3\%); (Imran et al., 2008), and Cameroon (3.3\%); (Ponkaet al.,2013).

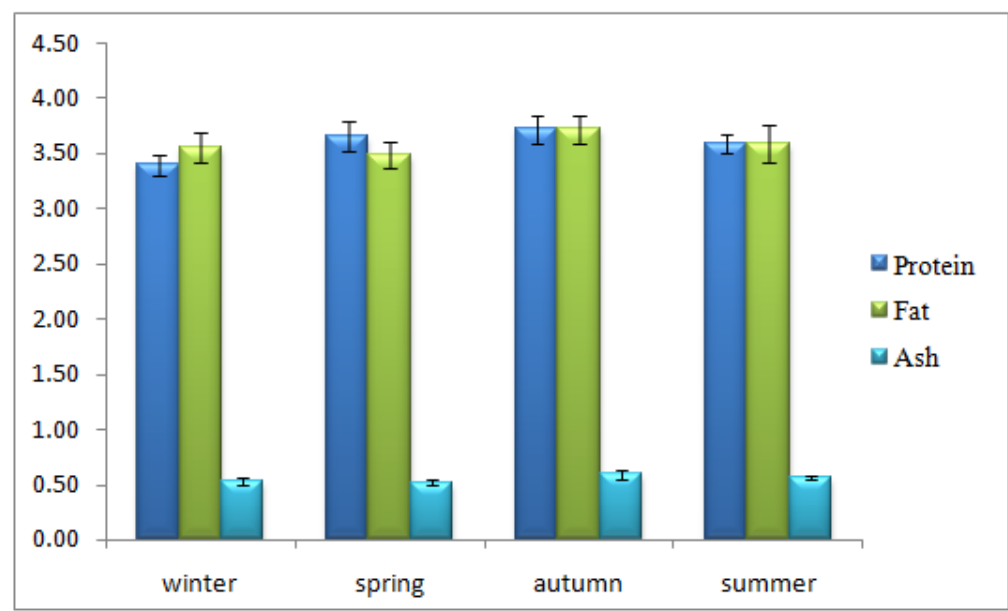

Figure 1.Chemical composition of Oulmescow raw milk during the fourth seasons. 
The average fat content rangedbetween 3 and $4.5 \%$, consistent withthe AFNOR value(3\%; AFNOR 2001) and similar studiesfrom Brazil (3.6\%) (Cofaniet al., 2009) and local Nguni cattle in South Africa (3.3\%; Mapekulaet al., 2011).Cows get dry food in winter and grass in summer as they are outside for a long time (Fox and Mcsweeney, 2003). Fat variabilitydepends on several factors such as the weather conditions, stage of lactation, and feeding. Milk protein content is alsosubject to seasonal changes and locality and its variabilityis known to behigher than that of fat content (Louwrenset al., 2000).

Ash content was $0.5 \%$ in spring and autumn (maximumof $0.6 \%$ ). This is consistent withthe ash content of $0.6 \%$ in milk from Cameroon (Ponkaet al., 2013) and $0.7 \%$ in Holstein Friesian cow milk ofSouth-Eastern Spain (Sanz Ceballos et al., 2009).The effect of seasonon ash content was small,consistent with results reported previously (Rao and Mishra, 2010).

\subsection{Fatty acid profiles}

In this phase of search work, the proportions of short-chain FAs (4:0, 6:0, 8:0, 10:0, and 12:0) in milk fat were not affected by the season. This was also the case for medium-chain FAs $(14: 0,16: 0$, and 16:1) in milk fat, the content of which was also similar between the four seasons except on summer $(\mathrm{C} 16: 0=22,086)$ and higher in the autumn $(\mathrm{C} 16: 0=24.063)$ compared to spring and winter (23.499 and 23.411).

Table 1.Amount of fatty acids $(\mathrm{g} / 100 \mathrm{~g})$ in milk fat of Oulmes breed determined by GC.

\begin{tabular}{|l|l|l|l|l|l|}
\hline & Winter & Spring & Autumn & Summer & \multirow{2}{*}{ SD } \\
\hline & Mean & Mean & Mean & Mean & \\
\hline C4:0 & $0.02^{\mathrm{a}}$ & $0.04^{\mathrm{a}}$ & $0.06^{\mathrm{a}}$ & $0.03^{\mathrm{a}}$ & 0.04 \\
\hline $\mathrm{C} 6: 0$ & $0.50^{\mathrm{ab}}$ & $0.68^{\mathrm{a}}$ & $0.41^{\mathrm{b}}$ & $0.32^{\mathrm{b}}$ & 0.16 \\
\hline $\mathrm{C} 10: 0$ & $0.76^{\mathrm{b}}$ & $1.04^{\mathrm{a}}$ & $0.62^{\mathrm{b}}$ & $0.79^{\mathrm{ab}}$ & 0.38 \\
\hline $\mathrm{C} 12: 0$ & $1.84^{\mathrm{ab}}$ & $2.06^{\mathrm{ab}}$ & $1.55^{\mathrm{b}}$ & $2.27^{\mathrm{a}}$ & 0.64 \\
\hline $\mathrm{C} 14: 0$ & $2.13^{\mathrm{ab}}$ & $2.23^{\mathrm{ab}}$ & $1.84^{\mathrm{b}}$ & $2.72^{\mathrm{a}}$ & 0.68 \\
\hline $\mathrm{C} 16: 0$ & $9.80^{\mathrm{b}}$ & $10.32^{\mathrm{ab}}$ & $9.92^{\mathrm{ab}}$ & $10.78^{\mathrm{a}}$ & 0.94 \\
\hline $\mathrm{C} 16: 1$ & $23.41^{\mathrm{b}}$ & $23.50^{\mathrm{b}}$ & $24.06^{\mathrm{ab}}$ & $22,08^{\mathrm{a}}$ & 1.61 \\
\hline C18:0 & $1.27^{\mathrm{ab}}$ & $1.81^{\mathrm{ab}}$ & $1.43^{\mathrm{a}}$ & $0.72^{\mathrm{b}}$ & 0.64 \\
\hline C18:1 n-9 & $35.13^{\mathrm{b}}$ & $22.19^{\mathrm{c}}$ & $25.28^{\mathrm{b}}$ & $27,41^{\mathrm{a}}$ & 4.57 \\
\hline C18:2 n-6 & $1.45^{\mathrm{a}}$ & $32.58^{\mathrm{a}}$ & $31.34^{\mathrm{a}}$ & $29,34^{\mathrm{b}}$ & 5.35 \\
\hline C20:0 & $0.22^{\mathrm{c}}$ & $0.56^{\mathrm{bc}}$ & $0.90^{\mathrm{b}}$ & $0.69^{\mathrm{c}}$ & 0.38 \\
\hline C24:0 & $0.54^{\mathrm{c}}$ & $1.35^{\mathrm{b}}$ & $1.26^{\mathrm{a}}$ & $1,05^{\mathrm{ab}}$ & 0.56 \\
\hline SFA & $64,36^{\mathrm{b}}$ & $63,99^{\mathrm{ab}}$ & $66,32^{\mathrm{b}}$ & $69,26^{\mathrm{a}}$ & 0.64 \\
\hline MUFA & $34,17^{\mathrm{a}}$ & $34,38^{\mathrm{a}}$ & $32,77^{\mathrm{ab}}$ & $30,06^{\mathrm{b}}$ & 1,72 \\
\hline PUFA & $1,45^{\mathrm{a}}$ & $1,62^{\mathrm{a}}$ & $0,90^{\mathrm{ab}}$ & $0,69^{\mathrm{b}}$ & 0,38 \\
\hline
\end{tabular}

Fatty acids: C4:0, butyric acid; C6:0, caproic acid; C8:0, caprylic acid; C10:0, capric acid; C12:0, lauricacid; C14:0, myristic acid; C16:0, palmitic acid;C16:1, palmitoleic acid; C18:0, stearic acid; C18:1, oleic acid; C18:2, linoleic acid; C20:0, arachidic acid ; C24:0, lignoceric acid, SD: standard deviation.

SFA = sum of saturated FA; MUFA = sum of monounsaturated FA; PUFA = sum of polyunsaturated FA.

${ }^{\text {abc }}$ Different letters for the seasons in the same parameterindicatesignificant difference $(\mathrm{P}<0.05)$.

These found results are consistent with those reported by Palmquistet al.,(1993), who reported a higher percentage in autumn $(\mathrm{C} 16: 0=30.78)$ than in summer $(\mathrm{C} 16: 0=28.76)$. While theC16 content in milk fat was not related to the feed, this fatty acid is partly derived from de novosynthesis (Agenaset al., 2002;Steinshamnet al., 2008).

Milk fat has not always had a good reputation due to its high saturated fatty acid content. However, saturated fatty acids are now regarded as not as"bad" as previously thought and also have very important functions. For instance, butyric acid (C4:0) hasa protective role against colon cancer (Senguptaet al., 2006) and the long fatty acids such as myristic acid (C14:0) specificallyacetylates proteinsso are considered active and useful to cellularfunction (Riouxet al., 2007).

Likewise, the saturated medium chain fatty acids (caproic acid C6, caprylic acid C8, and capric acid $\mathrm{C} 10)$ are an interesting group because they play a potential role in adiposity. Further, a study in rats and humans has suggestedthat diets rich in medium-chain fatty acids can help to reduce weight (Tsuji et al., 2001).

The majority of 18-carbon fatty acids in milk fat were affected by the season. The mean proportions of stearic acidbeing higher in summer $(\mathrm{C} 18: 0=27.4)$ in agreement with Prechet and Molkentin (1999) and Barbano (1990), who reported that the mean proportions of C18:0 were higher in summer and in spring.Moreover, C18:1 and C18:2 were higher in spring $(32.6 ; 1.6)$ and in winter $(32.9 ; 1.5)$, respectively, also in concordance with these two studies. Oleic acid (C18:1) and linoleic acid (18:2) are two fatty acids found in large quantities in fresh grass (Boufaïedet al, 2003; Jenkins et al., 2008) and must be ingested by cows to be secreted in milk. Feeding the cow is therefore of great importance with respect to the composition of unsaturated fatty acids in milk. 
Regarding mono-unsaturated fatty acids, there was little palmitoleic acid (C16:1) but a substantial amount of oleic acid (C18:1 n-9), which is considered a positive component of milk. Oleic acid is a precursor of long chain fatty acid derivatives (especially 24 carbons), a constituent of brain structures and particularly myelin. For the cardiovascular system, its neutrality is an important advantage and it is now accepted as a replacement to saturated fatty acids in the diet to reduce cholesterol (Gordon et al., 1995).

Furthermore, the concentrations of all 20:0 and 24:0fatty acidswere similar betweenthe four seasons, with higher percentages of both of these fatty acids in the summer. This change can be explained by the grazing period but also by supplementation with concentrate.

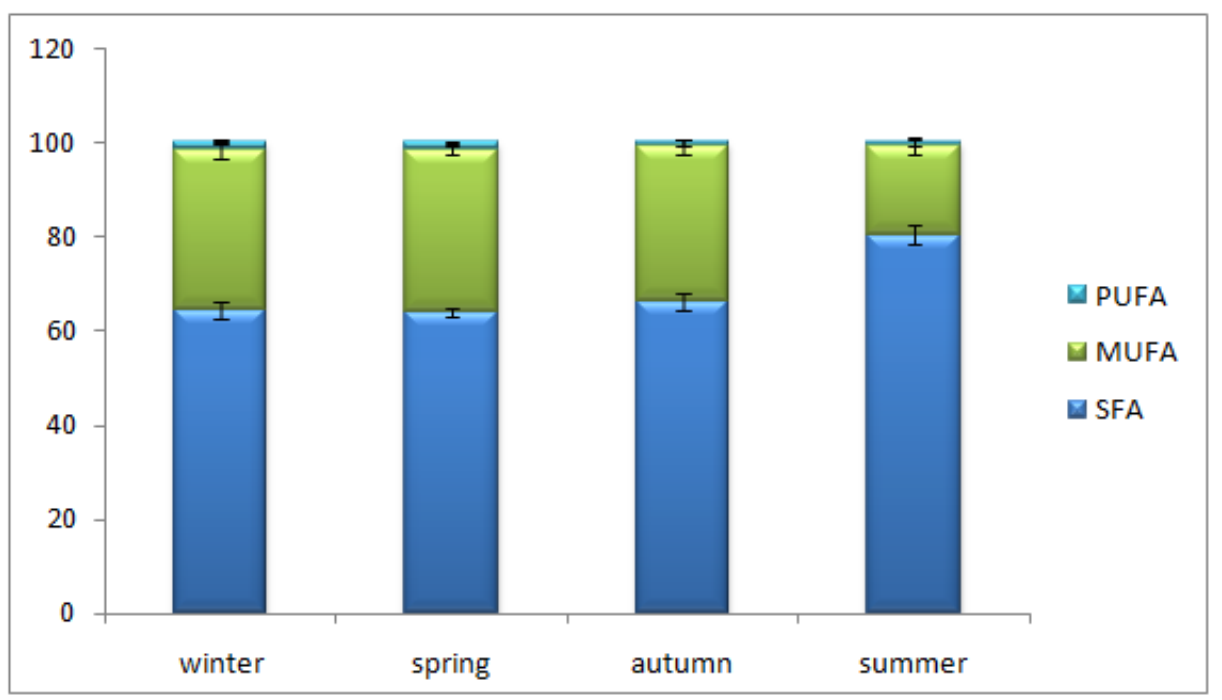

Figure 2: The SFA, MUFA and PUFA percentages of Oulmes bovine raw milk during the four seasons.

In the current study, the mean percentage of SFAsdid not change between seasons (Figure 2).However, the summer value (SFA=69.2) was higherthan that found by Prechetet al., (1999) (SFA=56.5) andsimilar to Prechetet al., (1999) during the winter (SFA=64.4 vs. 65.2). These percentages are also close to those found by Cortes et al.,(2010) for Holstein cow milk (SFA=71.3).

Nevertheless, the mean proportions of MUFAswere higher than those found by Prechetet al.,(1999)in the winter $(34.2 ; 19.3)$ and summer $(30.1 ; 21.4)$, respectively, and also higher than those reported by Cortes et al., 2010 (16.5).

Theessential polyunsaturated n-6 and n-3 fatty acids were not present at high levels in the milk fat. Nevertheless, improving the diet of animals can increase the n- 3 fatty acid content and make milk fat a greater source of $\alpha$-linolenic acid. Thus, since an excess of $n-6$ fatty acids is undesirable, the low content of PUFA milk fat can be an asset if care is taken to maintain very low n- 6 while increase $n-3$ in animal feed.

\section{Conclusion}

This study confirmed that there is a change in milk composition according to the season, in particular fatty acids, and this is probably due to an increased proportion of grass in the diet. The nutritional properties of milk can be improved cheaply by taking advantage of periods beyond full pasture (late winter or autumn). Milk fat has a specific composition that, whencompared qualitatively with "good" vegetable oils that provide polyunsaturated fatty acids (colza, nut), monounsaturated (olive), provides a natural complement to these fats by providing the fatty acids not found in oils. This interesting composition make the Oulmes raw milk a typical food product which could be encouraged as part of normal daily intake.

\section{References}

[1]. AFNOR, 2001- Lait - Détermination de la teneur en matière grasse - Méthode gravimétrique (méthode de référence). Nf en ISO $1211,21 \mathrm{P}$.

[2]. AFNOR, 1993 -Contrôle de la qualité des produits alimentaires : lait et produits laitiers : analyses physicochimiques. Paris La Défense : AFNOR, 4e éd., 581 p.

[3]. Agenas S, Holtenius K, Griinari M and Burstedt E, 2002. Effects of turn out to pasture and dietary fat supplementation on milk fat composition and conjugated linoleic acid in dairy cows. ActaAgricScand A Anim Sci52:25-33.

[4]. AKRAIM F. (2005) Effet du traitement thermique des graines de lin sur la biohydrogénationruminale des acides gras polyinsaturés et la qualité de la matière grasse du lait de vache. Thèse doctorat, Institut national polytechnique de Toulouse, option agronomie.

[5]. Barbano, D. M. 1990. Seasonal and regional variation in milk composition in the U. S. Proc. Cornell Nutr. Conf. Feed Manuf., CornellUniv., Ithaca, NY. 
[6]. Boufaïed, H., P. Y. Chouinard, G. F. Tremblay, H. V. Petit, R. Michaud, and G. Bélanger. 2003. Fatty acids in forages. II. In vitro ruminal biohydrogenation of linolenic and linoleic acids from timothy. Can. J. Anim. Sci. 83:513-522.

[7]. Boujenane I., (2002). Les races bovines au Maroc. Rabat :ActesÉdition, 144 p.

[8]. Chatibi S., (2011). La Filière viande bovine au Maroc quelle place pour l'élevage traditionnel et quelles bases de qualification pour la viande locale? Thèse pour obtenir le grade de docteur de l'Université de Corse, Ecole Doctorale Environnement et Société, France (392 pages).

[9]. Cofani L.G., Dos Santos A., Nadai F., Bacchi M.A., Adria G., Sarrie S., Blumer L., Barbosa F.J., (2009) .Chemical composition of bovine milkfrom Minas Gerais State, Brazil. J RadioanalNuclChem 282:493-496.

[10]. Côrtes C., da Silva-Kazama D.C., Kazama R., Gagnon N., Benchaar C., Santos G.T.D., Zeoula L.M., Petit H.V., (2010). Milk composition, milk fatty acid profile, digestion, and ruminal fermentation in dairy cows fed whole flaxseed and calcium salts of flaxseed oil. J. Dairy Sci., 93, 3146-3157.

[11]. Dewhurst, R. J.; Shingfield, K. J.; Lee, M. R. F.; Scollan, N. D., (2006). Increasing the concentrations of beneficial polyunsaturated fatty acids in milk produced by dairy cows in high-forage systems. Anim. Feed Sci. Technol., 131 (3-4): 168

[12]. Duckett, S. K.; J. G. Andrae; F. N. Owens. (2002). Effects of high oil corn or added corn oil on ruminal biohydrogenation of fatty acids and conjugated linoleic acid formation in beef steers fed finishing diets. J. Anim. Sci. 80: 3353-3360.

[13]. El-HamdaniMaha, Zaaraoui Linda, El HousniAbdellah, Bendaou Mohamed, Douaik Ahmed, ZouahriAbdelmajid, Ounine Khadija et Bouksaim Mohammed, (2016). Seasonal Effect on Bovine Raw Milk Composition of Oulmes Local Race in Morocco. Food Science and Quality Management. 52: 2224-6088.

[14]. Fox P.F., and Mcsweeney P.L.H. (2003). Advanced Dairy Chemistry, Vol. 1, Proteins (3rd Ed.,). London: Kluwer Academic/Plenum Publishers.

[15]. Gordon C.D., Kraemer H.C., 1995, Monounsaturated versus polyunsaturated dietary fat and serum lipids. A meta-analysis. ArteriosclerThrombVasc Biol., 15, 1917-1927.

[16]. Imran M., Khan H., Syed Shah H., and Khan R., (2008). Physicochemical characteristics of various milk samples available in Pakistan. Journal of Zhejiang University Science B9 (7): 54651.

[17]. Jenkins, T.C., Wallace, R.J., Moate, P.J. et Mosley, E.E. 2008. Board-invited review: Recent advances in biohydrogenation of unsaturated fatty acids within the rumen microbial ecosystem. J. Anim. Sci. 86:397-412.

[18]. Kjeldahl, J., 1983. Determination of protein nitrogen in food products. Encyc. Food Agric., 28:757-765. AOAC (Association of Official Analytical Chemists), 2000. Official Methods of Analysis International, 17th Ed. AOAC, Washington, DC.

[19]. Konyali A., Ayag B.S., and Yurdabak S. (2010). Effect of estrus synchronization on dairy goat milk composition.Afr J AgricRes, $5(8), 681-4$

[20]. Lecerf JM, 2008, Acides gras et maladies cardiovasculaires : De l'épidémiologie à la pratique clinique, Cholé-Doc, Centre de recherche et d'informations nutritionnelles, 110, 1-4.

[21]. Louwrens E. Smit, Hettie C. SchoKnfeldt, Willie H. J. de Beer and Marie F. Smith., (2000) The Effect of Locality and Season on the Composition of South African Whole Milk. Journal of food composition and analysis 13, 345$\} 367$.

[22]. Mapekula M., Chimonyo M., Mapiye C., Dzama K., (2011). Fatty acid, amino acid and mineral composition of milk from Nguni and local crossbred cows in South Africa. J. Food. Comp. Anal. 24: 529-536.

[23]. Mirzadeh K., Masoudi A., Chaji M., Bojarpour (2010). The composition of raw milk produced by some dairy frams in Lordegan region of Iran. J. Anim. Vet. Adv. 9: 1582-1583.

[24]. Palmquist, D. L., A. D. Beaulieu, and D. M. Barbano. 1993. Feed and animal factors influencing milk fat composition. J. Dairy Sci.76:1753-1771.

[25]. Ponka R., Beaucher E., Fokou E., Kansci G., Piot M., Leonil J., And Gaucheron F., (2013). Composition of raw cow milk and artisanal yoghurt collected in Maroua (Cameroon). African Journal of Biotechnology, Vol. 12(49), p. 6866-6875.

[26]. Pougheon S., (2001). Contribution à l'étude des variations de la composition du lait et ses conséquences en technologie laitière, Ecole Nationale Vétérinaire Toulouse, France: 34 (102 Pages).

[27]. Pouliot, Y. \& S. Gauthier, 2006. Milk growth factors as health products: Some technological aspects. International Dairy Journal, $16,1415-1420$.

[28]. Precht, D., and J. Molkentin. 1999. Analysis and seasonal variation of conjugated linoleic acid and further cis/trans-isomers of C18:1 and C18:2 in bovine milk fat. KielerMilchwirtsch. Forschungsber. 51:63-78

[29]. Quist M.A., Leblanc S.J., Hand K.J., Lazenby D., Miglior F., and Kelton D.F., (2008). Milking variability for milk yield, fat and protein percentage, and somatic cell count. J. Dairy Sci. 91:3412-3423.

[30]. Rao A., and Mishra S., (2010). An assessment of the nutritional profile of milk in different seasons and locations in Varanasi through modern laboratory techniques. Indian Journal of Preventive and Social Medicine, 41, 237-239.

[31]. Rioux V., Catheline D. and Legrand P., 2007, In rat hepatocytes, myristic acid occurs through lipogenesis, palmitic acid shortening and lauric acid elongation. Animal, 1, 820-826.

[32]. Sanz Ceballos L., Ramos Morales E., Adarve de la Torre G., Castro Díaz J., Martínez Pérez L., Sanz SampelayoRemedios M., (2009). Composition of goat and cow milk produced under similar conditions and analyzed by identical methodology. J. Food. Comp. Anal. 22: 322-329.

[33]. Sengupta S, Muir JG, Gibson PR. 2006, Does butyrate protect from colorectal cancer? GastroenterolHepatol. 21, 209-218

[34]. Steinshamn H and Thuen E, (2008). White or red clover-grass silage in organic dairy milk production: Grassland productivity and milk production responses with different levels of concentrate. LivestSci 119:202-215.

[35]. Tsuji H, Kasai M, Takeuchi H, Nakamura M, Okazaki M, Kondo K, 2001. Dietary medium-chain triacylglycerols suppress accumulation of body fat a double-blind, controlled trial in healthy men and women. J. Nutr, 131, 2853-9.

[36]. Yang L., Yang Q.,M.Yi, Pang Z.H., and Xiong B.H., (2013). Effects of seasonal change and parity on raw milk composition and related indices in Chinese Holstein cows in Northern China. J. Dairy Sci. 96:6863-6869. 